\title{
Floristic Survey of Epixylic Bryophytes of an Area Remnant of the Atlantic Forest (Timbaúba - PE, Brazil). 1. Hepaticopsida (except Lejeuneaceae) and Bryopsida
}

\author{
Shirley Rangel Germano \\ Kátia Cavalcanti Pôrto \\ Universidade Federal de Pernambuco - Departamento de Botânica \\ Av. Prof ${ }^{\circ}$ Nelson Chaves s/n, Recife - PE, Brazil. \\ CEP: $50.670-420$
}

\begin{abstract}
A survey of the epixylic bryoflora of a remaining Atlantic forest (seasonal coastal deciduous forest), Engenho Água Azul, in the municipality of Timbaúba ( Lat $7^{\circ} 35 \mathrm{~S}$; Long. $35^{\circ} 20 \mathrm{~W}$ ), State of Pernambuco, Brazil, registered 35 species of bryophytes distributed in 11 families of Bryopsida: Calymperaceae, Pilotrichaceae, Fissidentaceae, Hookeriaceae, Hypnaceae, Leucobryaceae, Leucomiaceae, Orthotrichaceae, Plagiotheciaceae, Sematophyllaceae, Thuidiaceae, and 5 of Hepaticopsida: Aneuraceae, Frullaniaceae, Geocalycaceae, Plagiochilaceae and Radulaceae. New records northeastern of Brazil are: Frullania caroliniana Sullivant, F. gymnotis Nees \& Mont., Ochrobryum stenophyllum Besch., Plagiochila trigonifolia Steph., Radula macrostachya Linbenb. \& Gott., Riccardia digitiloba (Spruce ex Steph.) Hell, Thuidium tomentosum Schimp. ex Besch. and Trichosteleum pusillum (Hornsch.) Jaeg. There is an indication of the description, illustration, and geographic distribution for Brazil of all taxons found.
\end{abstract}

Resumen: En este trabajo se presenta el catálogo de la flora briofítica epífita de la selva tropical oceánica Engenho Agua Azul, situada en el municipio de Timbaúba (Lat. $7^{\circ} 35 \mathrm{~S}$; Long. $35^{\circ} 20 \mathrm{O}$ ), perteneciente al estado de Pernambuco, Brasil. Se registraron 35 especies de briófitos distribuidas en 11 familias de la clase Bryopsida: Calymperaceae, Pilotrichaceae, Fissidentaceae, Hookeriaceae, Hypnaceae, Leucobryaceae, Leucomiaceae, Orthotrichaceae, Plagiotheciaceae, Sematophyllaceae, Thuidiaceae y 5 de la clase Hepaticopsida: Aneuracee, Frullaniaceae, Geocalycaceae, Plagiochilaceae y Radulaceae. Se aportan nuevas citas para la región nordeste del Brasil- Frullania caroliniana Sullivant, F. gymnotis Nees \& Mont, Ochrobryum stenophyllum Besch., Plagiochila trigonifolia Steph., Radulamacrostachya Linbenb. \& Gott., Riccardia digitiloba (Spruce ex Steph.) Hell, Thuidium tomentosum Schimp. ex Besch. y Trichosteleum pusillum (Horsnch.) Jaeg. Se presenta una descripción y una ilustración de cada taxon y se comenta su distribución geográfica. 


\section{INTRODUCTION}

The literature on humid tropical forests shows that the most favorable substrate for the establishment of bryophytes are live trunks, and dead trunks following in importance (Pócs 1982; Pôrto 1992). Richards classified the species that inhabit these substrates as: corticolous - when they colonize the cortex of live trunks and recently fallen branches, that have not decomposed; and the epixylic - when they colonize wood such as branches in decomposition. The authors have noticed that the occurrence of bryophyte carpets on robust and dead trunks (40-50 cm in diameter), especially those of hard wood, that have slow decomposition, and this enables intense colonization. This is due to the decomposition of the cellulose and of the lignin by micro-organisms, that provoke an increase in the porosity of the wood, and consequently in hydric retention, thus resulting that this substrate can be one of the most favorable microhabitants for hygrophilous and mesophilous plants, as is the case with bryophytes.

Exemplifying the relative works on the ecology of epixylic bryophytes, cite of Söderström (1987), who analysed the dispersion patterns of bryophytes occurring in 10 separate phytogeographic areas of devastated forests rich in fallen trees in the North of Sweden, and that of Sastre-De Jesús (1992) who worked in a rain forest in Pôrto Rico. She studied quantitatively the bryophytic communities of fallen trunks in different phases of decomposition, documenting the respective forms of growth.

In relation to the knowledge of the bryofloristic composition of Northwestern Brazil, it can be observed that the growth in the number of collections, has shown a relative richness in this group of cryptogams, principally in the remaining coastal Atlantic forests and in the higher altitude forests regionally known as brejo, where, in general, the humidity is higher. Besides this, even in the caatinga, we can find species adapted to the adverse climatic conditions (Yano \& AndradeLima 1987).

Concerning this subject, should be noted publications of Yano \& Andrade Lima (1987) who have made collections in various types of environments, from the coastal forests to the caatinga, adding 62 new records to the northeastern region; and Pôrto (1990) who made an inventory of the bryofloras at two forest reserves, Saltinho (50-120m. alt.) and Brejo dos Cavalos (890-1000m alt.) relating 170 species: 2 Anthocerotopsida, 89 Hepaticopsida and 79 Bryopsida, referring to each taxon growth form, substrate type, sporophyte occurrence and geographic distribution. Recently, Pôrto et al. (1993) identified for the Gurjaú Ecological Reserve (Cabo-PE), remmants of the Atlantic forests, 37 species, 20 Hepaticopsida and 17 Bryopsida, including Meiothecium revolubile Mitt. recorded for the first time in the Northeastern region.

The objective of this work is to expand the bryoflora knowledge of the State of Pernambuco, by way of surveys of epixylic bryophytes occurring in areas of coastal seasonal deciduous forests, remnants of the Atlantic forests, situated in Timbaúba-PE.

\section{METHODOLOGY}

\section{1 - Area of study}

The forest studied, Engenho Água Azul ( $7^{\circ} 35 \mathrm{~S}, 35^{\circ} 20 \mathrm{~W}$ and $210 \mathrm{~m}$. alt.), is located in the municipality of Timbaúba, Pernambuco, within the largest remaining area of the Atlantic Forest, with the Northern Forest gone from the State (Fidepe 1982).

The vegetation covering the area is classified as a seasonal coastal deciduous forest by Andrade-Lima (1970), because during the dry season the majority of the trees partially or totally lose their foliage. The area is crossed by the Coité creek, about 2.5 meters wide, perennial and torrential, with small waterfalls along its course. The climate is of the As tropical type, or rainy with a dry winter, following the classification by Koeppen. The annual average temperature is $25^{\circ} \mathrm{C}$ and the average precipitation is $1009.2 \mathrm{~mm}$.

\section{2-Collection and identification}

he bryophytes were collected in 6 bimonthly expeditions to the Engenho Água Azul forest, 
following the technique of Yano (1984b). The samples were taken from 54 fallen and dead trunks in a horizontal position, mostly located in the proximity of the Coité creek.

The classification system used for Hepaticopsida was that of Schuster (1984); accepting the terminology of Grolle (1983) and for Bryopsida it was Vitt (1984) with modifications from Buck and Vitt (1986) for the pleurocarpous. The geographic distribution for Brazil was based principally on the following works: Yano(1981, 1984a, 1989, 1991), Yano and Lisboa (1988), Pôrto (1990), SchäferVerwimp (1991), Behar et al. (1992), Yano and Mello(1992).

The vouchers were found deposited in the UFP Herbarium of the Department of Botany, Federal University of Pernambuco, Recife-PE.

\section{RESULTS}

The epixylic bryoflora of the studied forest is composed of 35 species, belonging to 11 Bryopsida families and 5 Hepaticopsida families. From these species, eight are new records for the Northeastern region.

The abbreviations of the Brazilian states utilized in the geographic distribution are related by region (see bottom of page).

\section{HEPATICOPSIDA}

\section{GEOCALYCACEAE}

Lophocolea martiana Nees G. L. \& N., Syn. Hep. 152.1845.

Material examined:S.R.Germano, 17-VII-92(UFP
8688), K.C.Pôrto, 11-IX-92(UFP9236).

Description and illustration: Fulford (1976).

Geographic distribution: AM, AP,ES, MG,PE,PR, RJ, RS, SC.

\section{PLAGIOCHILLACEAE}

* Plagiochila trigonifolia Steph., Bull. Herb. Boissier, sér. 2, 2:863. 1902.

Material examined:S.R. Germano, 17-VII-92(UFP 8671), K.C.Pôrto, 11-IX-92(UFP8690).

Description and illustration: Schiffner \& Arnell (1964).

Geographic distribution: SP.

\section{RADULACEAE}

* Radula macrostachya Lindenb. \& Gott., G.L.N., Syn. Hep. 726. 1847.

Materialexamined:S.R.Germano\&P.S.A.Sá, 6-V93(UFP8725), det. K. Yamada.

Description and illustration: Castle (1967).

Geographic distribution: AM, MG, PA, RS, SP.

Obs: * New record for Northeast Brazil.

\section{FRULLANIACEAE}

* Frullania caroliniana Sullivant, Musci Alleghanienses 64. 1846.

Material examined: S.R. Germano \& P.S.A. Sá, 6V-93(UFP8723).

Description and illustration:Lemos-Michel(1983). Geographic distribution: ES, RS.

* F. gymnotis Nees \& Mont., Ann. Sc. Nat. Paris. ser.II, 19:257. 1843.

Material examined: S.R. Germano, 9-II-93(UFP 8703), S. R. Germano \& P.S.A. Sá, 6-V-93 (UFP 8723).

Description and illustration:Lemos-Michel(1983). Geographic distribution: PA, RS, SP.

\begin{tabular}{|c|c|c|c|c|}
\hline NORTH & NORTHEAST & CENTRAL & SOUTHEAST & SOUTH \\
\hline Acre (AC) & Alagoas (AL) & Distrito Federal(DF) & Espírito Santo(ES) & Paraná (PR) \\
\hline Amapá (AP) & Bahia (BA) & Goiás (GO) & Minas Gerais(MG) & Rio G. do Sul(RS) \\
\hline Amazonas(AM) & Ceará (CE) & Mato Grosso(MT) & Rio de Janeiro(RJ) & Santa Catarina(SC) \\
\hline Pará (PR) & Maranhão(MA) & MatoG. do Sul(MS) & São Paulo (SP) & \\
\hline Rondônia (RO) & Paraíba (PB) & Tocantins (TO) & & \\
\hline Roraima (RR) & Pernambuco(PE) & & & \\
\hline
\end{tabular}


ANEURACEAE

* Riccardia digitiloba (Spruce ex Steph.) Hell, Bol.Fac. Filos. Ciênc.Univ. SãoPaulo 25:98.1969. Materialexamined:S.R. Germano, 17-VII-92(UFP 8670), K.C. Pôrto, 11-IX-92 (UFP 8695), S.R. Germano,9-II-93(UFP 8702).

Description and illustration: Hell (1969).

Geographic distribution: AM, MG, RJ, SP.

\section{BRYOPSIDA}

\section{FISSIDENTACEAE}

Fissidens guianensis Mont., Ann. Sci. Nat. Bot. sér.2, 14:340.1840.

Material examined:S.R. Germano, 11-IX-92(UFP 9247).

Description and illustration: Florschütz (1964). Geographic distribution: AM, MT, PE, RO.

F. inaequalis Mitt., J. Linn. Soc., Bot. 12:589. 1869.

Material examined: K. C. Pôrto, 11-IX-92 (UFP 9238).

Description and illustration: Florschütz (1964).

Geographic distribution: AM, PE.

F. pauperculus Howe, Erythea 2: 97. 1894. Material examined: S.R.Germano,17-VII-92(UFP 8674).

Description and illustration : Florschütz (1964). Geographic distribution:PE.

F. radicans Mont., Ann. Sci. Nat. Bot. sér.2, 14:345.1840.

Material examined: S.R. Germano, 9-II-93 (UFP 8719).

Description and illustration : Bruggeman-Nannenga \& Pursell (1990).

Geographic d

istribution: $\mathrm{BA}, \mathrm{PA}, \mathrm{PB}, \mathrm{PE}, \mathrm{PR}, \mathrm{RS}, \mathrm{SP}$.

F. zollingeri Mont., Ann. Sci. Nat. Bot. sér.3, 4:114.1845.

Materialexamined:K.C.Pôrto,11-IX-92(UFP9238).

Description and illustration: Florschütz (1964).

Geographic distribution: AM, BA, ES, GO, MA, MG, MS, PA, PB, PE, PR, RJ, RO, SC, SP.

LEUCOBRYACEAE
Leucobryum martianum (Hornsch.) Hampe, Linnaea 17:317.1843.

Materialexamined:K.C.Pôrto, 11-IX-92(UFP8748), S.R.Germano, 9-II-93 (UFP 8710).

Description and illustration: Yano (1992).

Geographic distribution: AC, AL, AM,CE,DF,ES, MA, MG, MT, PA, PE, PR, RJ, RR, SC, SP.

*Ochrobryum stenophyllum Besch.,J. Bot. 11:150. 1897.

Materialexamined: S.R.Germano, 17-VII-92(UFP 8679), S.R. Germano, 9-II-93 (UFP 8713).

Description and illustration: Yano (1992).

Geographic distribution: AC, AM, GO, MT, PA, RO.

Octoblepharum albidum Hedw., Spec. Musc. 50.1801.

Materialexamined: S.R. Germano, 17-VII-92(UFP 8676), S.R.Germano, 11-IX-92(UFP8719).

Description and illustration: Yano (1992).

Geographic distribution: AC, AL, AM, AP, BA, CE,DF,ES, GO,MA,MG,MS, MT,PA,PB,PE,PI, PR, RJ, RN, RO, RR, RS, SC, SE, SP.

\section{CALYMPERACEAE}

Calymperes afzelli Schwaegr., Jahrb. Gewachsk. 1:3.1818.

Material examined: S.R. Germano, 17-VII-92(UFP 8672).

Description and illustration: Reese (1993)

Geographic distribution: AC,ES, MT,PA, PE, RJ, RO, RR.

C. lonchophyllum Schwaerg., Spec. Musc., Suppl. 1(2):333.1816.

Material examined: K. C. Pôrto, 11-IX-92 (UFP 8689).

Description and illustration: Florschütz (1964).

Geographic distribution: AC, AL, AM, AP, ES, MA, MT, PA, PE, RO, RR, RJ, SP.

C. palisotii Schwaerg., Spec. Musc. Suppl. 1(2):334.1816.

Materialexamined:S.R. Germano, 17-VII-92(UFP 8684), S.R. Germano, 11-IX-92 (UFP 9260), S.R. Germano, 9-II-93(UFP8704).

Description and illustration: Reese (1993).

Geographic distribution: AL, AP, AM, BA, ES, GO, PA, PB, PE, PR, RJ, RN, RO. 
Syrrhopodon incompletus Schwaegr., Spec. Musc. Suppl.2(1):119.1824.

Material examined:S.R. Germano, 11-IX-92(UFP 9239), S.R. Germano, 11-IX-92(UFP9255).

Description and illustration: Lisboa (1993).

Geographic distribution: AC, AM, AP, GO, MG, MT, PE, RJ, RO, RR, SC, SP.

S. parasiticus (Schwaegr.) Besch., Ann. Sci. Nat. Bot. sér. 8, 1:298. 1895.

Material examined:S.R. Germano, 11-IX-92(UFP 9252), S.R. Germano, 9-II-92(UFP 8711).

Description and illustration: Lisboa (1993).

Geographic distribution: AM, BA, ES, MG, PA, PE,PR, RJ, RR, RO, SP.

\section{HOOKERIACEAE}

Callicostella pallida (Hornsch.) Angstr., Öfvers. Förh. Kongl. Svenska Vetensk.-Akad. 33(4):27.1876.

Material examined: S.R. Germano,17-VII-92(UFP 8671), K.C. Pôrto, 11-IX-92 (UFP 8696), S.R. Germano \& P.S.A.Sá, 6-V-93(UFP 8726).

Description and illustration: Florschütz-De Waard (1986).

Geographic distribution: AM, AP, ES, GO, MG, MT, PA, PE, PR, RJ, RR, RS, SP.

\section{PILOTRICHACEAE}

Pilotrichum evanescens (C. Muell.) C. Muell., Syn. Musc. Frond. 2:179. 1851.

Material examined: S.R.Germano, 17-VII-92(UFP 8671).

Description and illustration: Florschütz-De Waard (1986).

Geographic distribution: AM, MG, PA, PR, SC, SP.

\section{SEMATOPHYLLACEAE}

Meiothecium revolubile Mitt., J. Linn. Soc., Bot. 12:471.1869.

Material examined:S.R.Germano, 17-VII-92(UFP 8674).

Description and illustration: Behar et al. (1992).

Geographic distribution: AM, ES, MT, PE.

Pterogonidium pulchellum (Hook.) C. Muell, Bull. Herb. Boissier, 5:210.1897.

Material examined:S.R. Germano, 11-IX-92(UFP 8683).
Description and illustration: Sharp et al. (1994).

Geographic distribution: AM, PA, PE.

S. subpinnatum (Brid.) Britt., Bryologist, 21:28. 1918.

Material examined:S.R. Germano, 17-VII-92(UFP 8683), K.C. Pôrto, 11-IX-92 (UFP 9240), S.R. Germano, 11-IX-92 (UFP 9255), det. William R. Buck.

Description and illustration: Sharp et al. (1994).

Geographic distribution: AM, AP, CE, ES, GO, MG, MT, PA, PB, PE, PR, RJ, RR, RS, SC, SP.

S. subsimplex (Hedw.) Mitt., J. Linn.Soc. Bot. 12:44.1869.

Material examined: S.R. Germano, 17-VII-92(UFP 8677), K.C. Pôrto, 11-IX-92 (UFP 8747), S.R. Germano, 9-II-93(UFP 8705).

Description and illustration: Sharp et al. (1994).

Geographic distribution: AM, AP, DF, ES, GO, MA, MG, MT, PE, PB, PR, RJ, RR, RS, SC, SE, SP.

Sematophyllum sp.

Material examined: S.R.Germano, 17-VII-92(UFP 8748).

Comments: It was not possible to identifity the sample at specific level once that it was small and did not present sporophyte.

Taxithelium planum (Brid.) Mitt., J. Linn. Soc., Bot. 12:496.1869.

Material examined: S.R.Germano, 17-VII-92(UFP 8672), K.C. Pôrto,11-IX-92 (UFP 8695), S.R. Germano, 9-II-93(UFP8708).

Description and illustration: Buck (1985).

Geographic distribution: AC, AL, AM, AP, BA, ES, GO,MG, MT, PA, PB, PE, PR, RJ, RO, RR, SC, SP, TO.

Trichosteleum papillosum (Hornsch.) Jaeg., Ber. S. Gall. Naturv. Ges. 1876-77.419.1878. Material examined:S.R. Germano, 17-VII-92(UFP 8671),S.R.Germano,9-II-93(UFP8720), det.William R. Buck.

Description and illustration: Yano \& Lisboa(1988). Geographic distribution: AM, AP, ES, MG,PA,PE, RJ, RR, SC, SE, SP.

* T.pusillum(Hornsch.) Jaeg., Ber. S. Gall. Naturv. 
Ges. 1876-77.418.1878.

Material examined: S.R. Germano, 17-VII-92(UFP 8681), K.C.Pôrto,11-IX-92(UFP8693), det. William R. Buck.

Description: Mitten (1869) with Sematophyllum pusillum Hornsch.

Illustration: not found in the searched literature. Geographic distribution: RJ.

\section{HYPNACEAE}

Vesicularia sp.

Materialexamined:K.C.Pôrto, 11-IX-92(UFP8690). Comments: It was not possible to identify the sample at specific level once that it was small and did not present sporophyte.

\section{LEUCOMIACEAE}

Leucomium strumosum (Hornsch.) Mitt., J. Linn. Soc., Bot. 12:502. 1869.

Material examined:S.R. Germano, 17-VII-92(UFP 8688), S.R. Germano, 11-IX-92(UFP9248).

Description and illustration: Sharp et al. (1994).

Geographic distribution: AC, AM, AP, ES, MG, PA, PE, RJ, RO, RR, SC, SP.

\section{PLAGIOTHECIACEAE}

Pilosium chlorophyllum (Hornsch.) C. Muell., Flora 83:340.1897.

Material examined:S.R. Germano, 17-VII-92(UFP

8677), K. C. Pôrto, 11-IX-92(UFP8700).

Description and illustration: FlorschützDe-Waard (1986).

Geographic distribution: AL, AM, AP, ES, MG, MT, PA, PE, RJ, RR, SP.

\section{THUIDIACEAE}

* Thuidium tomentosum Schimp. ex Besch., Mém. Soc. Sci. Nat. Cherbourg. 16:273. 1872.

Materialexamined:K.C.Pôrto, 11-IX-92(UFP8690).

Description and illustration: Sharp et al. (1994).

Geographic distribution: ES, PE.

\section{ORTHOTRICHACEAE}

Groutiella mucronifolia (Hook. et Grev.) Crum et Steere, Bryologist 53:146. 1950.

Materialexamined:S.R.Germano,9-II-93(UFP8717).

Description and illustration: Lisboa (1993).

Geographic distribution: BA, MT, PA, PE, RJ, SP.
Schlotheimia jamesonii(Arn.) Brid., Spec. Musc. Suppl. 2(1):150.139.1824.

Material estudado: S.R. Germano, 7-VII-92(UFP 8683).

Description and illustration: Mello \& Yano(1991). Geographic distribution: AM, BA, GO, MG, MT, PE, PR, RJ, RS, SC, SP.

\section{FINALCONSIDERATIONS}

In the humid forests, trunks in decomposition are substrates densely colonized by bryophytes (Pócs 1982, Richards 1957). This is confirmed by the present work, with Hepaticopsida and Bryopsida well represented on these substrates, with a total of 54 species, and 35 are related in this article. Given their importance, the 19 representatives of Lejeuneaceae will be the object of another article, containing keys, descriptions, and illustrations of the taxa.

Richards (1984) related that in the humid forests of South America, the populations of epixylic bryophytes consist principally of pleurocarpous mosses (Sematophyllum subsimplex, Taxithelium planum) and various Hookeriaceae, though acrocarpous mosses, in turfs, being common, like Calymperes lonchophyllum, Leucobryum martianum, Octoblepharum albidum and other Leucobryaceae.

Analyzing this information with that obtained in the studied area, Richards noticed that pleurocarpous moss families (7) were

better represented than those of the acrocarpous mosses (4), but in terms of species richness there was not a significative difference between the two.

When one compares the studied bryoflora, as cited by Pôrto (1990) for the same type of substrate, one can find a coincidence of about $50 \%$ of the species. About this subject, the same author, calls attention to the fact that the epixylic species found are usually be found to occur on other types of substrates, not being exclusively epixylic, growing in various proportions on soil, termite hills, and live trunks. This is also confirmed 
by Sastre-De Jesús (1992) who studied the colonizing bryophytes of fallen trunks in decomposition in a subtropical forest of Puerto Rico. Registering a total of 40 species, of which $20 \%$ were common with the ones listed in this work.

However, it is important to point out that this small percentage of coincident species, can be due to the fact that the referred author worked in a homogeneous community dominated by one species of Phanerogam, Dacryodes excelsa (Burseraceae), while in the studied forest, the species were collected from native trunks of numerous host Phanerogams.

This was the first work done in the Northeastern region of Brazil directed at the community of colonizing bryophytes from dead trunks, a substrate of great importance in environments of humid tropical forests. New research in this area are necessary to amplify the knowledge of the local bryoflora, such as, to study the physicalchemical relation between these cryptogams and the substrate in question.

\section{ACKNOWLEDGMENTS}

To Dr. Kohasaka Yamada - Hattori Botanical Laboratory (Japan), Dr. Olga Yano - Botany Institute (Brazil), and Dr. William R. Buck - New York Botanical Garden (USA), who have graciously confirmed the identification of some species.

\section{REFERENCES}

Andrade - Lima, D. 1970. Recursos vegetais de Pernambuco. Bull. Téc. Inst. de Pesq. Agron. 4b1-32.

Behar, L., Yano, O. \& Vallandro, G.C. 1992.Briófitas da restinga de Setiba, Guarapari (Espírito Santo).Bol. Mus. Biol. Mello Leitão 1:25-28.

Bruggeman-Nannenga, M.A \& Pursell, R.A. 1990. The Fissidens radicans complex.(Section Amblythallia) in the neotropics and paleotropics. Bryologist 93(3):332-340.

Buck, W.R. 1985. A review of Taxithelium (Sematophyllaceae) in Brasil. Acta Amazônica 151-2 Supl.):43-53.

Buck, W.R. \& Vitt, D.H. 1986. Suggestion for a new familial classification of pleurocarpous mosses. Taxon 35(1): 21-60.

Castle, H. 1967. A revision of the genus Radula. Part. II. Subgenus Acroradula. Section 11 Complanate. Revue Bryologique et Lichenologique 35(1-4):1-94.

FIDEPE - Fundação de Informações para o desenvolvimento de PerNambuco. Recife, 1982. 76p. (Monografias Municipais,10).

Florschütz, P.A. 1964. The mosses of Suriname. Leiden: E.J. Brill. 271p.

Florschütz-de Waard, J. 1986. Flora of Suriname. v. VI. Part.I. Musci. Leiden: E.J. Brill, p. 273-361.

Fulford, M. 1976. Manual of the leafy Hepaticae of Latin America. Memoirs of The New York Botanical Garden 11(4):393-535.

Grolle, R. 1983. Nomina generica Hepaticarum; references, types and synonymies. Acta Bot. Fennica $121: 1-62$

Hell, K.C. 1969. Briófitas talosas dos arredores da cidade de São Paulo (Brasil). Bol. Fac. Filos. Ciên. Univ. São Paulo 25:1-190.

Lemos-Michel, E. L. 1983. Frullania ( Jungermaniales, Hepaticopsida) no Rio Grande do Sul, Brasil. I. Subgênero Diastaloba . Revta. brasil. Bot. 6(2):115123.

Lisboa, R.C.L. 1993. Musgos acrocárpicos de Rondônia. Mus. Par. Emílio Goeldi 272p.

Mello, Z.R. \& Yano, O. 1991. Musgos do manguezal do Rio Guaraú, Peruíbe, São Paulo. Revta. brasil. Bot. 14:35-44.

Mitten, W. 1869. Musci Austro-american. J. Linn. Soc. Bot. 12:1-659.

Pócs, T. 1982. The Tropical Bryophytes. In: Smith, A.J.E., Bryophyte Ecology, London: Chapman and Hall, p.54-104.

Pôrto, K.C. 1990. Bryoflores dune fôret de plaine et dune fôret daltitude moyenne dans lÉtat de Pernambuco (Brésil): Analyse floristique. Cryptogamie, Bryol. Lichénol. 11:19-161.

Pôrto, K.C. 1992. Bryoflores dune fôret de plaine et dune fôret daltitude moyenne dans l'Etat de Pernambuco(Brésil): 2. Analyse écologique comparative des fôrets. Cryptogamie, Bryol. Lichénol. 13(3):187-219

Pôrto, K.C.; Macedo, A.M.; Fônseca, E.R. \& Silva, E.C. 1993. Brioflora da reserva de Gurjaú, Cabo (PE). Biologica Brasilica 5(1/2):27-42.

Reese, W.D. 1993. Calymperaceae: Flora neotropica Monograph 58:1-1-102.

Richards, P.W. 1957. The tropical rainforest. Cambridge: 
Cambridge University Press. 450p.

Richards, P.W. 1984. The ecology of tropical forest bryophytes. In: Schuster, R.M. New Manual Bryology, Rudolph. M. Schuster ed., v.2, p.1233-1970.

Sastre-de Jesús, I. 1992. Estudos preliminares sobre comunidades de Briófitos en troncos en decomposicion en el bosque subtropical lluvioso de Puerto Rico. Tropical Bryology 6:181-191.

Schäfer-Verwimp, A. 1991. Contribution to the knowledge of the Bryophyte flora of Espírito Santo, Brasil. J. Hattori Bot. Lab. 69:47-170.

Schiffner, V. \& Arnell, S. 1964. Engebnisse der Botanichen Expedition der kaiserlichen Akademie der Weissenschaffen nach Südbrasilien 1901. Öster. Akad. Wiss., Math. - Nat. kl; Denkschr. 111:1-56.

Schuster, R.M. 1984. Evolution, phylogeny and classification of Hepaticae. In: New Manual of Bryology (R. M. Schuster, ed.) p. 892-1070, Nichinan.

Sharp, A.J., Crum, H. \& Eckel, P.M. 1994. The Moss Flora of Mexico. Part one: Sphagnales to Bryales. Part two: Orthotrichales to Polytrichales. Mem. New York Bot. Gard. 69:1-1113.

Söderström, L. 1987. Dispersal as a limiting factor for distribution, among epixylic bryophytes. Symposia Biologica Hungarica 35:475-483.

Vitt, D.H. 1984. Classification of the Bryopsida. In: Schuster, R.M. New Manual of Bryology: p.696-759, Nichinan.

Yano, O.1981. A checklist of Brazilian mosses. J. Hattori. Bot. Lab. 50:279-456.

Yano, O. 1984 a. Checklist of Brazilian liverworts and hornworts. J. Hattori. Bot. Lab. 56:481-548.

Yano, O. 1984 b. Briófitos. In: Fidalgo, O. \& Bononi, V.L.R. (Coord.) Técnicas de coletas, preservação e herborização de material São Paulo: Inst. de Botânica, $66 \mathrm{p}$.

Yano, O. 1989. An additional checklist of brazilian bryophytes. J. Hattori Bot. Lab. 66:371-434.

Yano, O. 1991. Novas localidades de musgos nos estados do Brasil. Acta Amazônica 22(2):197-218.

Yano, O. .1992. Leucobryaceae (Bryopsida) do Brasil. Tese. (Doutorado em Ciências). Instituto de Biociências de São Paulo. São Paulo. 318p.

Yano, O. \& Andrade - Lima, D. 1987. Briófitas do Nordeste brasileiro: Estado de Pernambuco. Revta. brasil. Bot. 10:171-181.

Yano, O. \& Lisboa, R.C.L. 1988. Briófitas do Território Federal do Amapá, Brasil. Bol. Mus. Par. Emílio Goeldi 4(2). (Série Botânica).

Yano, O. \& Mello, R.R. de 1992. Briófitas novas para o Estado de Roraima, Brasil. Acta Amazonica 22(1): $23-50$ 